\title{
PELATIHAN DAN PENDAMPINGAN PENYUSUNAN SISTEM INFORMASI PELAPORAN KEUANGAN DESA BAGI PERANGKAT DESA SE - KECAMATAN GUNUNG SARI, LOMBOK BARAT
}

\author{
Oleh : \\ Eni Indriani \\ Fakultas Ekonomi dan Bisnis Universitas Mataram \\ eni.indriani@unram.ac.id \\ Bq. Rosyida Dwi Astuti \\ Fakultas Ekonomi dan Bisnis Universitas Mataram \\ Robith Hudaya \\ Fakultas Ekonomi dan Bisnis Universitas Mataram \\ robith.hudaya@unram.ac.id
}

\section{Article History:}

Received: -

Revised: -

Accepted: -
Abstract: Every year the Central Government has budgeted a large enough Fund to be given to the Village. For this reason, villages are required to be able to submit an accountability report for the funds that have been given. For this reason, a village financial reporting information system is needed that will provide accurate and timely information so that village financial management activities can be carried out effectively and efficiently. The community service activities are held in Gunung Sari sub-district, West Lombok which aims to provide adequate knowledge about the benefits of using information systems in preparing village financial reports; provide training and assistance in the preparation of a village financial reporting information system, and assistance in the preparation of village financial reports. The series of community service activities that have been carried out are running smoothly. All participants enthusiastically participated in the event until the end and felt the benefits of the training for village financial management.

Abstrak: Setiap tahun Pemerintah Pusat telah menganggarkan Dana Desa yang cukup besar untuk diberikan kepada Desa. Untuk itu, desa dituntut 


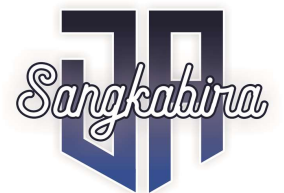

Vol. 1, No. 1, Desember 2020

untuk dapat menyampaikan laporan
pertanggungjawaban atas dana yang sudah
diberikan. Untuk itu diperlukan suatu sistem
informasi pelaporan keuangan desa akan
menyediakan informasi yang akurat dan tepat waktu
sehingga aktivitas pengelolaan keuangan desa dapat
dilakukan secara efektif dan efisien. Adapun
kegiatan pengabdian pada masyarakat ini
diselenggarakan di kecamatan Gunung Sari, Lombok
Barat yang bertujuan untuk memberikan
pengetahuan yang memadai mengenai manfaat
penggunaan sistem informasi dalam penyusunan
laporan keuangan desa; memberikan pelatihan dan
pendampingan penyusunan sistem informasi
pelaporan keuangan desa, dan pendampingan
penyusunan laporan keuangan desa. Rangkaian
kegiatan pengabdian pada masyarakat yang telah
dilaksanakan berjalan lancar. Semua peserta
antusias mengikuti acara hingga selesai dan
merasakan manfaat pelatihan bagi pengelolaan
keuangan desa.

Keywords: Village Fund, Accountability Report, Effectively, Efficiently.

Kata kunci: Dana Desa, Laporan Pertanggungjawaban, Efektif, Efisien. 


\section{PENDAHULUAN}

Desa diberikan kewenangan dan sumber dana yang memadai agar dapat mengelola potensi yang dimilikinya guna meningkatkan ekonomi dan kesejahtaraan masyarakat. Setiap tahun Pemerintah Pusat telah menganggarkan Dana Desa yang cukup besar untuk diberikan kepada Desa. Pada tahun 2015, Dana Desa dianggarkan sebesar Rp. 20,7 triliun, dengan rata-rata setiap desa mendapatkan alokasi sebesar Rp.280.000.000,-. Pada tahun 2016, Dana Desa meningkat menjadi Rp. 46,98 triliun dengan rata-rata setiap desa sebesar Rp. 628.000.000,- dan di tahun 2017 kembali meningkat menjadi Rp. 60 Triliun dengan rata-rata setiap desa sebesar Rp. 800.000.000,-.

Jumlah Dana Desa yang cukup besar ini memerlukan pengawasan. Pengawasan pelaksanaan kegiatan di tingkat desa dilakukan oleh Pemerintah Pusat, Pemerintah Propinsi, Pemerintah Kabupaten/Kota. Pembinaan dan pengawasan ini dapat didelegasikan kepada perangkat desa atau BPD (badan musyawarah desa). Namun demikian, terkait aspek pengawasan ini masih perlu ditingkatkan lagi. Sebagaimana pernah disampaikan oleh wakil ketua KPK bahwa "ada lima persoalan yang ditemukan dari segi pelaksanaan yaitu kerangka waktu situs pengelolaaan anggaran desa sulit dipatuhi oleh desa, belum tersedianya aturan harga baku barang atau jasa yang dijadikan acuan bagi desa dalam menyusun APBDesa, masih rendahnya transparansi rencana penggunaan dan pertanggungjawaban APBDesa. Selain itu, laporan pertanggungjawaban yang dibuat desa belum mengikuti standar dan rawan manipulasi. Serta, APBDesa yang disusun tidak sepenuhnya menggambarkan kebutuhan yang diperlukan desa" (https://nasional.sindonews.com)

Pelaporan Dana Desa ini tidak dapat dihindari karena pelaporan keuangan merupakan bentuk akuntabilitas desa kepada pemangku kepentingan, diantaranya masyarakat dan negara (pemerintah pusat). Dengan demikian, pelaporan keuangan Dana Desa menjadi keharusan, dan potensi masalah pun sudah tampak di depan mata jika kesiapan SDM tidak memadai/mendukung. Selain itu, sistem informasi yang baik juga akan menjadi kendala jika tidak dikelola dengan baik, khususnya sistem informasi terkait dengan pelaporan keuangan desa. Sistem informasi pelaporan keuangan desa akan menyediakan informasi yang akurat dan tepat waktu sehingga aktivitas pengelolaan keuangan desa dapat dilakukan secara efektif dan efisien. Selain itu, penggunaan aplikasi sistem informasikan meningkatkan kualitas pelaporan dan mengurangi biaya pemrosesan akuntansi.

Gunung Sari merupakan salah satu kecamatan di wilayah Kabupaten Lombok Barat yang memiliki potensi ekonomi cukup besar. Beberapa desa yang berada di wilayah ini merupakan sentra produksi kerajinan yang cukup terkenal di NTB, diantaranya adalah Desa Sesela 


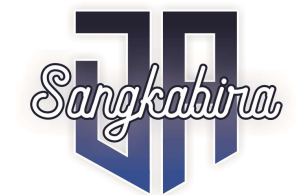

Vol. 1, No. 1, Desember 2020

yang dikenal dengan kerajinan cukli dan ukiran, dan desa gunung sari dengan kerajinan berbahan utama bambu. Dana desa yang diperoleh tentunya akan dapat meningkatkan potensi ekonomi yang dimiliki wilayah ini jika dapat dikelola dengan baik. Untuk itu, dana desa ini perlu dikawal pengelolaannya oleh berbagai pihak. Namun demikian, perangkat desa sebagai pengelola keuangan desa belum memiliki kualifikasi dan kompetensi untuk mengelola dengan baik, sehingga berbagai upaya untuk meningkatkan pengetahuan dan kompetensi pengelolaan ini perlu untuk dilakukan. Salah satunya adalah melalui kegiatan pendidikan dan pelatihan penyusunan laporan keuangan guna meningkatkan akuntabilitas pengelola keuangan desa terhadap dana yang dipercayakan kepada mereka.

Berdasarkan uraian masalah atau tantangan yang akan dihadapi oleh pemerintah desa terkait dengan turunnya Dana Desa ini, maka Tim Pengabdian Kepada Masyarakat (PPM) kami menilai perlu melakukan pendampingan bagaimana menyusun sistem pelaporan keuangan Dana Desa. Hal ini didasari pertimbangan, kebutuhan yang mendesak untuk melakukan pencatatan keuangan yang andal dan transparan sebagai bentuk akuntabilitas pengelolaan dana desa. Target dari kegiatan ini adalah para pengelola keuangan yang terdiri dari kepala, sekretaris dan bendahara desa di Kecamatan Gunung sari, Lombok Barat. Kegiatan direncanakan akan dilakukan melalui kegiatan pelatihan, pendampingan, dan penyediaan aplikasi sistem informasi pelaporan keuangan.

Kegiatan pengabdian pada masyarakat ini memiliki tujuan antara lain untuk: 1) Memberikan pengetahuan yang memadai mengenai manfaat penggunaan sistem informasi dalam penyusunan laporan keuangan desa ; 2) Memberikan pelatihan dan pendampingan penyusunan sistem informasi pelaporan keuangan desa ; 3) Melakukan pendampingan penyusunan laporan keuangan desa. Sehingga diharapkan setelah memperoleh pendampingan akan dapat memberikan manfaat bagi pengelola keuangan desa berupa pengetahuan yang memadai tentang pengelolaan keuangan desa, pengetahuan tentang manfaat sistem informasi dalam penyusunan laporan keuangan desa. Dan terbangunnya sistem informasi pelaporan keuangan desa yang akan mempermudah perangkat pengelola desa dalam meyusun laporan keuangan desa.

Khalayak sasaran yang diundang pada pelatihan ini adalah Perangkat desa dalam hal ini adalah staf pengelola keuangan di kecamatan Gunung Sari yang terdiri dari 16 desa. Penetapan sasaran ini sebagai upaya meningkatkan pemahaman para pengelola keuangan desa tentang penyusunan laporan keuangan Dana Desa di Kecamatan Gunung Sari, Lombok Barat. Pelaksanaan kegiatan pengabdian kepada masyarakat ini dilaksanakan mulai awal bulan Oktober, mundur dua bulan dari jadwal, yang terkendala oleh karena situasi masyarakat pulau Lombok yang terdampak oleh bencana alam gempa bumi yang mengakibatkan banyak 
prasarana hancur dan kegiatan pemerintahan yang lebih mengutamakan penanggulangan bencana alam.

\section{Metode Pelaksanaan Kegiatan}

Kegiatan pengabdian ini dilakukan dengan sistematika pelaksanaan kegiatan sebagai berikut:

1. Pelatihan.

Peserta diberikan materi bagaimana menyusun laporan keuangan yang memadai sebagai bentuk pertanggungjawaban.

2. Tutorial.

Peserta diberikan materi dan dipandu dalam menggunakan aplikasi Siskeudes dan materi aplikasi komputer akuntansi untuk usaha dagang dan jasa yang akan diaplikasikan oleh Bada Usaha Milik Desa (Bumdes).

3. Diskusi.

Peserta pelatihan diberikan kesempatan untuk mendiskusikan permasalahan yang berkaitan dengan penyusunan laporan keuangan yang selama ini mereka dihadapi.

4. Pendampingan.

Setelah memperoleh materi tentang pemahaman akuntansi desa dan penyusunan sistem informasi akuntansi keuangan desa, selanjutnya tim melakukan pendampingan penyusunan laporan keuangan.

\section{HASIL}

Kegiatan pengabdian dimulai dengan penelusuran informasi terkait dengan pengelolaan keuangan desa yang dilakukan di Kantor Camat Gunung Sari. Informasi diperoleh dari staf kecamatan, tentang jumlah desa yang ada di kecamatan Gunung Sari dan informasi tentang adanya Pendamping Dana Desa dalam menyusun laporan keuangan. Berdasarkan informasi dari staf kecamatan tersebut, tim pengabdian kemudian menghubungi Pendamping Pengelolaan Dana Desa Kabupaten Lombok Barat. Dari pendamping ini diperoleh informasi tentang kebutuhan materi dari pengelola dana desa. Tim kemudian menyusun materi pelatihan dan membuat aplikasi akuntansi sederhana yang berbasis komputer untuk usaha dagang dan jasa bagi Bumdes, karena usaha yang banyak dikembangkan oleh Bumdes adalah Usaha dagang seperti Bumdesmart.

Kegiatan Pelatihan pengelolaan keuangan dan akuntansi desa dilaksanakan pada 3 November 2018, bertempat di Kantor Desa Midang. Pelatihan dihadiri oleh 22 orang perangkat desa dan staf pengelola 


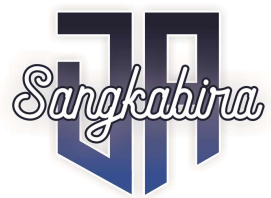

Vol. 1, No. 1, Desember 2020

keuangan dari 16 desa yang ada di kecamatan Gunung Sari. Kegiatan pelatihan dibuka oleh Pak Dr. Ali Fikri (Ketua Jurusan Akuntansi FEB Unram) sebagai perwakilan lembaga dan Pak Ardian Zamzami, SE yang merupakan Pendamping Desa Kabupaten Lombok Barat.

Pelatihan dimulai dengan diskusi singkat untuk melihat pemahaman peserta tentang Dana desa dan akuntansi desa. Penyampaian materi Akuntansi Desa disajikan oleh Nara Sumber Ibu Biana Adha Inapty, SE., M.Si., yang merupakan Pakar di bidang Akuntansi Sektor Publik yang disela waktu penyajian materi diselingi dengan diskusi dengan peserta. Selanjutnya kegiatan dilanjutkan dengan pemberian Tutorial penggunaan aplikasi Siskeudes dan aplikasi akuntansi sederhana untuk usaha dagang dan jasa Bumdes disajikan oleh Ibu Bq. Rosyida Dwi Astuti, SE., M.Si., Ak. Sebelumnya peserta sudah diberikan soft file aplikasi dalam format Excel dan hard copy manualnya, yang kemudian dipandu penggunaannya oleh penyaji. Penerapan aplikasi ini akan selanjutnya terus dipantau melalui kegiatan pendampingan.

\section{KESIMPULAN}

Rangkaian kegiatan pengabdian pada masyarakat yang telah dilaksanakan berjalan lancar. Semua peserta antusias mengikuti acara hingga selesai dan merasakan manfaat pelatihan bagi pengelolaan keuangan desa. Sehingga dapat disimpulkan bahwa tercapai tujuan dari kegiatan pengabdian berupa :

1. Memberikan pengetahuan yang memadai mengenai manfaat penggunaan sistem informasi dalam penyusunan laporan keuangan desa.

2. Memberikan pelatihan penyusunan sistem informasi pelaporan keuangan desa.

3. Melakukan pendampingan penyusunan laporan keuangan desa.

Mengingat besarnya manfaat dari kegiatan pengabdian pada masyarakat untuk memberikan informasi dan pengetahuan yang aplikatif mengenai Pengelolaan Keuangan Desa, maka kegiatan sejenis ini perlu terus untuk dilaksanakan. Karena tim meyakini bahwa upaya sekecil apapun jika dilakukan secara terus menerus dan berkesinambungan akan memberikan hasil yang lebih besar dan bermanfaat. 


\section{DAFTAR PUSTAKA}

https://nasional.sindonews.com/read/1012030/13/kpk-temukan-14potensi-masalah-pengelolaan-dana-desa-1434116438. Diunduh tanggal 10 Maret 2018

Kementerian Keuangan Republik Indonesia, Buku Pintar Dana Desa. 2017.

Republik Indonesia, PP No. 60 Tahun 2014 Tentang Dana Desa yang Bersumber dari Anggaran Pendapatan dan Belanja Negara. 